\title{
Bilateral Upper Limb Neuropathies After Prone Ventilation for COVID-19 Pneumonia
}

William K. Diprose, MBChB, Laura Bainbridge, MBChB, Richard W. Frith, MBChB, and Neil E. Anderson, MBChB

Neurology: Clinical Practice April 2021 vol. 11 no. 2 e211-e213 doi:10.1212/CPJ.0000000000000944
Correspondence

Neil E. Anderson

NeilA@adhb.govt.nz

The neurologic complications of coronavirus disease 2019 (COVID-19) and its treatment are still being elucidated. ${ }^{1,2}$ Guillain-Barré syndrome has been reported in patients with COVID-19, but other peripheral nerve complications have not been described. We report a case of bilateral upper limb neuropathies in a patient with COVID-19 pneumonia managed with prolonged prone ventilation.

\section{Case}

A 55-year-old woman with a body mass index of 42.6, but who was otherwise fit and well, presented with a seven-day history of cough, fever, and shortness of breath. Her oxygen saturation was $87 \%$ on room air. Chest radiograph demonstrated patchy airspace opacification (figure, A), and her severe acute respiratory syndrome coronavirus 2 (SARS-CoV-2) reverse transcription PCR test was positive. She was managed with high-flow oxygen via nasal prongs, and her oxygen saturation improved to $93 \%$. Within 24 hours, she deteriorated and required intubation and ventilation for refractory hypoxemia.

Because of ongoing hypoxemia in the supine position, she was ventilated in a prone "swimmer's" position for 16-18.5 hours per day for the first 7 days. The face was turned toward the prominent (abducted) arm, leaving the opposite arm by the side. The elbow of the prominent arm was flexed to $90^{\circ}$ and abducted at the shoulder to $80^{\circ}$. The shoulder was not externally rotated beyond neutral. The arms were alternated and head turned every 2 hours.

The patient improved, and the neuromuscular blockade and sedation were withdrawn after 11 days. When clinically accessible, the patient was unable to lift her arms off the bed, but there was no neck or arm pain. After extubation, a neurology opinion was sought. On examination, there was severe bilateral weakness of shoulder abduction and external rotation, mild weakness of finger abduction, and numbness over the distribution of the axillary nerves bilaterally. Upper limb tendon reflexes and the remainder of the neurologic examination were normal. MRI of the cervical spine and the nerves within the brachial plexus was normal, but there was symmetric short $\mathrm{T} 1$ inversion recovery hyperintense signal within the supraspinatus, infraspinatus, and deltoid muscles bilaterally (figure, B).

Electromyography (EMG) showed complete denervation of deltoid muscles bilaterally and of right infraspinatus. There was partial denervation of right supraspinatus and of the right ulnarinnervated intrinsic hand muscles (table). Muscles innervated by the left suprascapular nerve were difficult to examine because of patient intolerance. The EMG of biceps and brachioradialis bilaterally and right pronator teres were normal. Nerve conduction studies showed prolongation of the right median distal motor latency and absent sensory potentials consistent with a distal median neuropathy at the right wrist. Ulnar motor and sensory conduction studies were normal.

\section{MORE ONLINE}

COVID-19 Resources

For the latest articles, invited commentaries, and blogs from physicians around the world

NPub.org/COVID19 

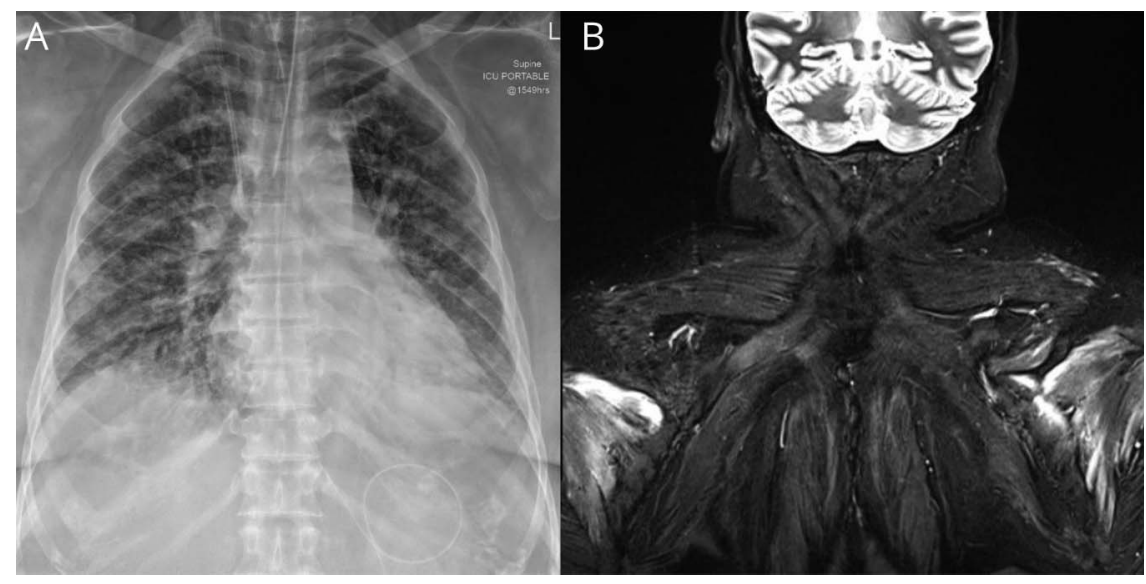

(A) Chest radiograph showing patchy midzone and lower zone airspace opacification. Central line, endotracheal, and enteric tubes in situ. (B) Symmetric short T1 inversion recovery hyperintense signal within the infraspinatus muscles bilaterally.

Together, the clinical, imaging, and electrophysiologic findings were consistent with bilateral suprascapular, axillary, and ulnar neuropathies.

\section{Discussion}

Our patient developed bilateral upper limb neuropathies after prolonged prone ventilation. The differential diagnosis included brachial neuritis and mechanical injury (i.e., stretch or compression) secondary to positioning during prone ventilation. There was involvement of the axillary and suprascapular nerves, with sparing of brachioradialis and biceps, confirming these were individual nerve lesions rather than lesions of the upper trunk of the brachial plexus or C5-6 roots. This pattern of multifocal nerve involvement is more consistent with brachial neuritis

Table Electromyography in a Patient With COVID-19 After Prone Ventilation ${ }^{a}$

\begin{tabular}{|c|c|c|c|c|}
\hline Muscle & Fibrillations & Recruitment pattern & MUAP amplitude & MUAP duration \\
\hline \multicolumn{5}{|l|}{ Right side } \\
\hline Triceps brachii & 0 & $\mathrm{~N}$ & $\mathrm{~N}$ & $\mathrm{~N}$ \\
\hline Biceps brachii & 0 & $\mathrm{~N}$ & $\mathrm{~N}$ & $\mathrm{~N}$ \\
\hline Deltoid & $3+$ & No activity & & \\
\hline Brachioradialis & 0 & $\mathrm{~N}$ & $\mathrm{~N}$ & $\mathrm{~N}$ \\
\hline Pronator teres & 0 & $\mathrm{~N}$ & $\mathrm{~N}$ & $\mathrm{~N}$ \\
\hline First dorsal interosseous & $2+$ & Reduced 2+ & $\mathrm{N}$ & $\mathrm{N}$ \\
\hline Abductor digiti minimi & $2+$ & Reduced 2+ & $\mathrm{N}$ & $\mathrm{N}$ \\
\hline Extensor indicis & 0 & $\mathrm{~N}$ & $\mathrm{~N}$ & $\mathrm{~N}$ \\
\hline Opponens pollicis & 0 & Reduced 1+ & $1+$ & $1+$ \\
\hline Infraspinatus & $3+$ & No activity & & \\
\hline Supraspinatus & 0 & Reduced 2+ & $1+$ & $2+$ \\
\hline \multicolumn{5}{|l|}{ Left side } \\
\hline Deltoid & $3+$ & No activity & & \\
\hline Biceps brachii & 0 & $\mathrm{~N}$ & $\mathrm{~N}$ & $\mathrm{~N}$ \\
\hline Brachioradialis & 0 & $\mathrm{~N}$ & $\mathrm{~N}$ & $\mathrm{~N}$ \\
\hline
\end{tabular}


than stretch or compressive neuropathies, which typically affects the upper trunk. ${ }^{3,4}$

Brachial neuritis has not yet been described in association with COVID-19, but other presumed immune-mediated neurologic complications have been reported including Guillain-Barré syndrome, acute transverse myelitis, acute hemorrhagic necrotizing encephalopathy, and encephalitis. ${ }^{2}$ Brachial neuritis may result from the interplay between mechanical and immune factors, whereby mechanical injury exposes the brachial plexus to the immune system, and possibly (auto)antibodies to recent infections. ${ }^{3}$ For example, when a region in Czechoslovakia had its water supply contaminated with coxsackie A2 virus, an increased incidence of brachial neuritis occurred in knitting factory workers who were required to bend and stretch their right arms for 8 hours per day. ${ }^{5}$

Prone positioning is recommended for the treatment of refractory hypoxemia associated with severe COVID-19 pneumonia, even in awake patients, to avoid the need for intubation. ${ }^{6}$ Our patient had prolonged prone ventilation, which can be associated with neurologic complications including ischemic optic neuropathy and brachial plexus injury. ${ }^{7,8}$ Shoulder abduction greater than $90^{\circ}$, extension and external rotation of the arm, and rotation and lateral flexion of neck in the same direction are risk factors for brachial plexus injury during prone ventilation. ${ }^{7}$ This risk may be minimized by frequent repositioning, soft padding, and increased clinician awareness. ${ }^{7}$ It is plausible that in our patient, prolonged prone ventilation caused injury to the bloodnerve barrier of the brachial plexus and predisposed the patient to developing bilateral brachial neuritis.

\section{Study Funding}

No targeted funding reported.

\section{Disclosure}

The authors report no disclosures relevant to the manuscript. Full disclosure form information provided by the authors is available with the full text of this article at Neurology.org/cp.

\section{Publication History}

Received by Neurology: Clinical Practice May 29, 2020. Accepted in final form July 17, 2020.

Appendix Authors

\begin{tabular}{lll}
\hline Name & Location & Contribution \\
\hline $\begin{array}{l}\text { William K. } \\
\text { Diprose, } \\
\text { MBChB }\end{array}$ & $\begin{array}{l}\text { Auckland City } \\
\text { Hospital, } \\
\text { Auckland, NZ }\end{array}$ & $\begin{array}{l}\text { Background research, first draft of } \\
\text { the manuscript, and revision of } \\
\text { the manuscript for intellectual } \\
\text { content }\end{array}$ \\
\hline $\begin{array}{l}\text { Laura } \\
\text { Bainbridge, } \\
\text { MBChB }\end{array}$ & $\begin{array}{l}\text { Middlemore } \\
\text { Auckland, NZ }\end{array}$ & $\begin{array}{l}\text { Background research and revision } \\
\text { of the manuscript for intellectual } \\
\text { content }\end{array}$ \\
$\begin{array}{l}\text { Richard W. } \\
\begin{array}{l}\text { Frith, } \\
\text { MBChB }\end{array}\end{array}$ & $\begin{array}{l}\text { Auckland City } \\
\text { Hospital, }\end{array}$ & $\begin{array}{l}\text { Background research and revision } \\
\text { of the manuscript for intellectual } \\
\text { content }\end{array}$ \\
$\begin{array}{l}\text { Neil E. } \\
\text { Anderson, } \\
\text { MBChB }\end{array}$ & $\begin{array}{l}\text { Auckland City } \\
\text { Hospital, }\end{array}$ & $\begin{array}{l}\text { Background research and revision } \\
\text { of the manuscript for intellectual } \\
\text { content }\end{array}$ \\
\hline
\end{tabular}

\section{References}

1. Nath A. Neurologic complications of coronavirus infections. Neurology 2020;94: 809-810.

2. Ahmad I, Rathore FA. Neurological manifestations and complications of COVID-19: a literature review. J Clin Neurosci 2020;77:8-12.

3. Van Eijk JJJ, Groothuis JT, Van Alfen N. Neuralgic amyotrophy: an update on diagnosis, pathophysiology, and treatment. Muscle Nerve 2016;53:337-350.

4. Kamel I, Barnette R. Positioning patients for spine surgery: avoiding uncommon position-related complications. World J Orthop 2014;5:425-443.

5. Bardos V, Somodska V. Epidemiologic study of a brachial plexus neuritis outbreak in northeast Czechoslovakia. World Neurol 1961;2:973-979.

6. Berlin DA, Gulick RM, Martinez FJ. Severe Covid-19. N Engl J Med 2020;383: 2451-2460.

7. DePasse JM, Palumbo MA, Haque M, Eberson CP, Daniels AH. Complications associated with prone positioning in elective spinal surgery. World J Orthop 2015;6 351-359.

8. Goettler CE, Pryor JP, Reilly PM. Brachial plexopathy after prone positioning. Crit Care 2002;6:540-542. 


\section{Neurology ${ }^{\circ}$ Clinical Practice}

Bilateral Upper Limb Neuropathies After Prone Ventilation for COVID-19 Pneumonia

William K. Diprose, Laura Bainbridge, Richard W. Frith, et al.

Neurol Clin Pract 2021;11;e211-e213 Published Online before print August 18, 2020

DOI 10.1212/CPJ.0000000000000944

This information is current as of August 18, 2020

Updated Information \&

Services

References

Citations

Subspecialty Collections

Permissions \& Licensing

Reprints including high resolution figures, can be found at:

http://cp.neurology.org/content/11/2/e211.full.html

This article cites 8 articles, 1 of which you can access for free at: http://cp.neurology.org/content/11/2/e211.full.html\#\#ref-list-1

This article has been cited by 1 HighWire-hosted articles:

http://cp.neurology.org/content/11/2/e211.full.html\#\#otherarticles

This article, along with others on similar topics, appears in the

following collection(s):

All Clinical Neurology

http://cp.neurology.org//cgi/collection/all_clinical_neurology

COVID-19

http://cp.neurology.org//cgi/collection/covid_19

Peripheral neuropathy

http://cp.neurology.org//cgi/collection/peripheral_neuropathy

Information about reproducing this article in parts (figures,tables) or in its entirety can be found online at:

http://cp.neurology.org/misc/about.xhtml\#permissions

Information about ordering reprints can be found online:

http://cp.neurology.org/misc/addir.xhtml\#reprintsus

Neurol Clin Pract is an official journal of the American Academy of Neurology. Published continuously since 2011, it is now a bimonthly with 6 issues per year. Copyright () 2020 American Academy of Neurology. All rights reserved. Print ISSN: 2163-0402. Online ISSN: 2163-0933.

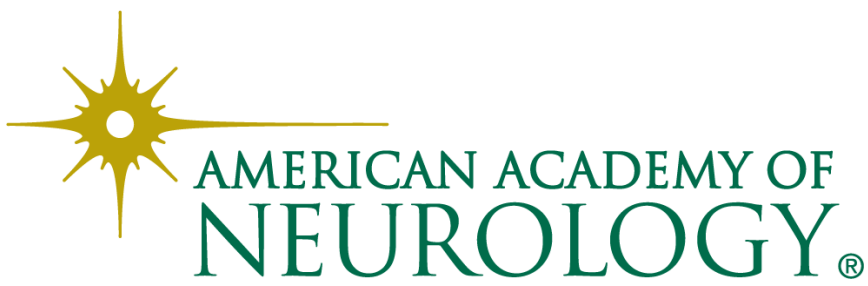

